\title{
Analisis Pengaruh Faktor Kritis pada Keberhasilan Proyek Data Desa Presisi
}

\author{
Raden Rara Indriyati Kusumawardani Mulyoningtyas* \\ Program Studi Magister Manajemen, Sekolah Tinggi Manajemen PPM \\ Jl. Menteng Raya 9, Jakarta Pusat, Indonesia \\ rara.indriyati@gmail.com \\ Alain Widjanarka Handaka \\ Program Studi Magister Manajemen, Sekolah Tinggi Manajemen PPM \\ Jl. Menteng Raya 9, Jakarta Pusat, Indonesia \\ alainwidjanarka@gmail.com
}

Diterima: 30-07-2021 | Disetujui: 24-12-2021 | Dipublikasi: 31-01-2022

(C) (i) This work is licensed under a Creative Commons Attribution 4.0 International License.

\begin{abstract}
ABSTRAK
Tujuan penelitian ini adalah untuk mengungkapkan faktor kritis yang memengaruhi keberhasilan proyek Data Desa Presisi (DDP), faktor kritis yang memiliki efek/dampak tertinggi pada pelaksanaan proyek DDP, dan tingkat pengaruh faktor kritis pada keberhasilan proyek DDP. Penelitian ini menggunakan pendekatan kuantitatif yang didukung dengan data kualitatif. Unit analisis dalam penelitian ini adalah enumerator, tim proyek, dan pemerintah desa yang terlibat dalam proyek DDP. Teknik pengambilan sampel yang digunakan adalah metode sensus dengan jumlah responden sebanyak 141 orang. Data dikumpulkan melalui kuesioner dengan skala likert, untuk kemudian dianalisis dengan Partial Least Square (PLS). Penelitian dilaksanakan di 6 Desa yaitu Desa Sukamantri (Bogor), Desa Tegallalang (Gianyar Bali), Desa Cihideung Ilir (Bogor), Desa Cibanteng (Bogor), Desa Gelar Anyar (Cianjur), dan Desa Bantar Jaya (Bogor). Hasil uji signifikansi parameter individual (Uji-t) menunjukkan bahwa faktor manajemen proyek dan rencana tenaga kerja berpengaruh positif dan signifikan secara parsial terhadap keberhasilan proyek DDP. Pada hasil uji simultan (Uji F) menunjukkan bahwa seluruh faktor pada dimensi faktor penentu keberhasilan berpengaruh positif dan signifikan terhadap keberhasilan proyek DDP secara simultan.
\end{abstract}

Kata Kunci:

Faktor-faktor Kritis Keberhasilan; Keberhasilan Proyek; Data Desa Presisi; Partial Least Square.

\begin{abstract}
The purpose of this study is to reveal the critical factors that influence the success of the Precision Village Data $(D D P)$ project, the critical factors that have the highest effect/ impact on the implementation of the DDP project, and the degree of influence of critical factors on the success of the DDP project. This research uses a quantitative approach supported by qualitative data. The units of analysis in this research are the enumerators, the project team, and the village government involved in the DDP project. The sampling technique used is the census method, with a total of 141 respondents. Collected data was through a questionnaire with a Likert scale, then analyzed by Partial Least Square (PLS). The research was conducted in 6 villages namely Sukamantri Village (Bogor), Tegallalang Village (Gianyar Bali), Cihideung Ilir Village (Bogor), Cibanteng Village (Bogor), Gelar Anyar Village (Cianjur), and Bantar Jaya Village (Bogor). The results of the individual parameter significance test ( $t$ test) show that the project management CSFs and workforce plans have a positive and partially significant effect on the success of the DDP project. Furthermore, the simultaneous test results (F test) show that all the factors in the dimensions of the CSFs have a positive and significant effect on the success of the DDP project simultaneously.
\end{abstract}

Keywords:

Critical Success Factors; Project Success; Precision Village Data; Partial Least Square 


\section{PENDAHULUAN}

Saat ini, desa semakin memiliki peran strategis melalui berbagai program yang dimiliki sesuai dengan kewenangan dan kebutuhannya. Merujuk UU Nomor 6 tahun 2014, desa berwenang untuk mengatur dan mengurus tata kelola yang dibutuhkan di wilayahnya. Hal tersebut termasuk urusan pemerintahan maupun kepentingan masyarakat setempat. Desa dikelola dengan mempertimbangkan peran masyarakat, hak asal usul, dan/ atau hak tradisional, yang diakui serta dihormati dalam sistem pemerintahan Negara Kesatuan Republik Indonesia. Posisi strategis desa diakui dengan adanya alokasi dana desa, dari Pemerintah Pusat, yang bertambah besar seperti dilihat pada tabel 1 .

Tabel 1. Kebijakan Dana Dari Pemerintah Pusat Ke Desa

\begin{tabular}{ccccc}
\hline Tahun & 2015 & 2016 & 2017 & 2018 \\
\hline Dana Desa (Triliun Rupiah) & 20,67 & 46,98 & 60,00 & 60,00 \\
\hline \multicolumn{6}{c}{ Sumber: Kementerian Keuangan (2018) } \\
\hline
\end{tabular}

Pengaturan pengalokasian dana kepada desa dengan mempertimbangkan status kemajuan dan kemandirian desa. Direktorat Jenderal Pembangunan dan Pemberdayaan Masyarakat Desa, Kementerian Desa menemukan bahwa pada tahun 2020, terdapat 19,96\% atau 13.961 desa tergolong tertinggal dan 3,52\% atau 2.465 desa yang tergolong sangat tertinggal (Kemendes, 2020). Alokasi dana desa berdasarkan kebutuhan pembangunan desa yang sejalan dengan perencanaan pembangunan negara. Pemerintah pusat membutuhkan data yang sesuai dengan kondisi nyata demi menghasilkan kebijakan alokasi dana desa yang tepat.

Pengelolaan data menjadi hal yang penting demi penyelarasan pembangunan desa dengan perencanaan pembangunan secara menyeluruh. Melalui Peraturan Presiden No. 39/2019 tentang Satu Data Indonesia, Pemerintah Pusat berupaya untuk mencegah penyimpangan data dari desa hingga pusat. Kondisi geografis Indonesia membuat data yang ada akan sangat beragam dan bersifat majemuk, sehingga berdampak pada rendahnya tingkat akurasi data. Data potensi desa yang dimiliki oleh Badan Statistik Nasional (BPS) dan digunakan untuk mengukur kemajuan desa, saat ini memiliki tingkat akurasi yang rendah. Tiga unsur penting dalam menghasilkan sumber data desa adalah efisien, efektif, dan presisi (Sjaf et al., 2020). Efisien artinya pengambilan data tidak membutuhkan biaya besar; efektif artinya pengambilan, validasi, dan verifikasi data bisa dilakukan oleh warga desa dengan bantuan pihak luar desa; dan presisi artinya data akurat dan tepat sebagaimana kondisi aktual yang ada di desa.

Perguruan tinggi, dengan pengetahuan dan kemampuan yang dimiliki, merupakan pihak yang dipandang mampu untuk mewujudkan data desa yang presisi. Kerjasama yang terjadi antara pihak perguruan tinggi dan warga desa dapat menghasilkan data yang akurat sesuai konteks sosial, ekonomi dan budaya setempat. Institut Pertanian Bogor (IPB University) merupakan perguruan tinggi di Indonesia yang membenahi tingkat akurasi data desa. Melalui Lembaga Penelitian dan Pengabdian kepada Masyarakat (LPPM) yang dimiliki, IPB University mengembangkan Data Desa Presisi (DDP) dengan pendekatan Drone Participatory Mapping (DPM). 
Penyusunan DDP dikelola dengan pendekatan manajemen proyek. Pendekatan tersebut merupakan suatu proses perencanaan, pengorganisasian, pengarahan, dan pengendalian sumberdaya. Proses tersebut saling terkait demi menyelesaikan tujuan dan sasaran tertentu (Kerzner, 2017). Tantangan yang dihadapi proyek DDP adalah keterbatasan sumber daya, faktor risiko yang tinggi, serta keragaman karakteristik desa. Masalah saat pelaksanaan proyek DDP mulai dari masalah teknis maupun non teknis, yang bersifat internal proyek maupun eksternal proyek. Oleh karena itu identifikasi dan pemahaman faktor kritis perlu diketahui sebelum proyek dilaksanakan (Jitpaiboon et al., 2019).

Faktor kritis penentu keberhasilan proyek atau Critical Success Factors (CSFs) merupakan bagian penting yang mendukung keberhasilan pelaksanaan suatu proyek. Kelemahan dari bagian tersebut dapat membawa dampak pada kegagalan proyek mencapai target atau sasaran tertentu. Penelitian mengenai faktor kritis telah dilakukan oleh beberapa peneliti. Natalia et al. (2017) berpendapat bahwa proyek konstruksi memiliki lima elemen yang mempengaruhi faktor kritis, yaitu manajer proyek, tim proyek, proyek itu sendiri, organisasi, dan lingkungan eksternal. (Maqbool \& Sudong, 2018) mengatakan bahwa pada proyek energi terbarukan, faktor kritis yang paling memberikan dampak pada keberhasilan proyek adalah lingkungan. Selain itu ada faktor kritis lain yang perlu diperhatikan juga seperti: komunikasi, tim proyek, faktor teknis, dan faktor organisasi. Zachawerus \& Soekiman (2018) melihat bahwa dalam proyek jalan nasional di Maluku Utara ditemukan 10 faktor kritis. Faktor kritis tersebut adalah keahlian teknis dari manajer, implementasi penjaminan mutu, manajer proyek, penjadwalan, sistem komunikasi, mekanisme kontrol, komitmen pihak di dalam proyek, keterlibatan manajer proyek, pengawasan kualitas konstruksi, dan keahlian teknis tim supervisi. Jitpaiboon et al. (2019) menyarankan tiga faktor kritis untuk menentukan kinerja proyek; yaitu: perangkat manajemen proyek, pengalaman penyelenggaraan proyek, dan dukungan manajemen. Li $e t$ al. (2019) berpendapat bahwa untuk melaksanakan proyek green building diperlukan faktor kritis yaitu: komunikasi dan kerjasama tim proyek, perencanaan dan pengendalian proyek, keterlibatan dan komitmen pemilik, tujuan dan sasaran proyek, dan kinerja manajer proyek. Kepemimpinan manajer proyek juga menjadi penentu keberhasilan proyek (Gasemagha \& Kowang, 2021).

Proyek dikatakan berhasil apabila hasil akhir yang diperoleh jauh lebih baik dari perkiraan awal. Indikator keberhasilan proyek dari waktu ke waktu semakin berkembang. Saat ini kesuksesan proyek selain dari waktu, biaya, dan mutu, juga dilihat dari dampaknya pada keberhasilan bisnis, manfaat yang diterima pemangku kepentingan, dan manfaat yang diterima anggota pelaksana proyek (Machado \& Martens, 2015; Moradi et al., 2020). Kesuksesan proyek juga mempertimbangkan tingkat kolaborasi antar anggota tim proyek. Kolaborasi semakin meningkat berdasarkan kinerja proyek dan penyelarasan pengetahuan dan inovasi (Bond-Barnard et al., 2018). Iriarte \& Bayona (2020) berpendapat bahwa kesuksesan proyek dapat dilihat dari 2 sisi yaitu kesuksesan manajemen dalam menangani proyek dan kebermanfaatan hasil proyek.

Faktor kritis penentu keberhasilan proyek merupakan variabel laten yang diukur menggunakan beberapa indikator. Pengukuran variabel laten hanya dapat dilakukan dengan menggunakan beberapa 
indikator. Identifikasi variabel laten dan indikator yang digunakan dalam penelitian terdahulu dapat dilihat pada tabel 2 .

Tabel 2. Identifikasi Variabel Laten dan Indikator

\begin{tabular}{|c|c|c|c|}
\hline No & Variabel Laten & Indikator & Sumber \\
\hline 1 & $\begin{array}{l}\text { Manajemen } \\
\text { Proyek (MP) }\end{array}$ & $\begin{array}{ll}\text { - } & \text { Sistem komunikasi pihak yang terlibat (MP1) } \\
\text { - } & \text { Jadwal yang digunakan (MP2) } \\
\text { - } & \text { Efektifitas membuat keputusan (MP3) } \\
\text { - } & \text { Mengembangkan struktur organisasi yang tepat (MP4) } \\
\text { - } & \text { Pelatihan SDM untuk kebutuhan skill proyek (MP6) } \\
\text { - } & \text { Implementasi program penjaminan mutu yang efektif (MP7) } \\
\text { - } & \text { Implementasi program keselamatan yang efektif (MP8) } \\
\text { - } & \text { Ketersediaan anggaran (MP9) } \\
\text { - } & \text { Identifikasi dan alokasi risiko (MP10) } \\
\text { - } & \text { Komitmen semua pihak yang terlibat pada proyek (MP11) } \\
\text { - } & \text { Tujuan dan sasaran yang jelas (MP12) }\end{array}$ & $\begin{array}{l}\text { (Gasemagha \& } \\
\text { Kowang, 2021; Li } \\
\text { et al., 2019; } \\
\text { Maqbool \& } \\
\text { Sudong, 2018; } \\
\text { Natalia et al., } \\
\text { 2017; Zachawerus } \\
\text { \& Soekiman, } \\
\text { 2018) }\end{array}$ \\
\hline 2 & $\begin{array}{l}\text { Pengadaan } \\
\text { Proyek (PP) }\end{array}$ & $\begin{array}{l}\text { - } \quad \text { Sistem penyelenggaraan proyek (PP1) } \\
\text { - } \quad \text { Metode penawaran proyek (PP2) } \\
\text { - }\end{array}$ & $\begin{array}{l}\text { Natalia et al. } \\
(2017)\end{array}$ \\
\hline 3 & $\begin{array}{l}\text { Faktor } \\
\text { Eksternal (FE) }\end{array}$ & $\begin{array}{ll}\text { - } & \text { Lingkungan ekonomi (FE1) } \\
\text { - } & \text { Lingkungan sosial (FE2) } \\
\text { - } & \text { Lingkungan kerja (FE3) } \\
\text { - } & \text { Kondisian teknologi (FE4) } \\
\text { - } & \text { Keterlibatan pemangku kepentingan secara aktif (FE6) } \\
\text { - } & \text { Kebijakan dan regulasi pemerintah (FE7) }\end{array}$ & $\begin{array}{l}\text { (Li et al., 2019; } \\
\text { Maqbool \& } \\
\text { Sudong, 2018; } \\
\text { Natalia et al., } \\
\text { 2017; Zachawerus } \\
\text { \& Soekiman, } \\
\text { 2018) }\end{array}$ \\
\hline 4 & $\begin{array}{l}\text { Kompetensi } \\
\text { Manajer } \\
\text { Proyek }(\mathrm{KM})\end{array}$ & $\begin{array}{ll}\text { - } & \text { Pengalaman manajer proyek (KM1) } \\
\text { - } & \text { Keterampilan mengorganisir manajer proyek (KM2) } \\
\text { - } & \text { Keterlibatan mananajer proyek dari awajer proyek (KM3) } \\
& \text { proyek (KM4) } \\
\text { - } & \text { Keterampilan koordinasi manajer proyek (KM5) } \\
\text { - } & \text { Hubungan manajer proyek dengan pihak lain (KM6) }\end{array}$ & $\begin{array}{l}\text { Zachawerus \& } \\
\text { Soekiman (2018) }\end{array}$ \\
\hline 5 & $\begin{array}{l}\text { Kompetensi } \\
\text { Tim Supervisi } \\
\text { (KT) }\end{array}$ & $\begin{array}{ll}\text { - } & \text { Kemampuan keahlian teknis tim supervisi (KT1) } \\
\text { - Kemampuan pengawasan kegiatan oleh tim supervisi } \\
\text { (KT2) } \\
\text { - } \quad \text { Keterampilan koordinasi tim supervisi (KT3) }\end{array}$ & $\begin{array}{l}\text { Zachawerus \& } \\
\text { Soekiman (2018) }\end{array}$ \\
\hline 6 & $\begin{array}{l}\text { Rencana } \\
\text { Tenaga Kerja } \\
\text { (RT) }\end{array}$ & $\begin{array}{ll}\text { - } & \text { Jumlah tenaga kerja yang direncanakan (RT1) } \\
\text { - Keahlian tenaga kerja berdasarkan pengalaman (RT2) } \\
\text { - Keahlian tenaga kerja berdasarkan tingkat Pendidikan } \\
\text { - } \quad \text { Produktivitas tenaga kerja (RT4) }\end{array}$ & $\begin{array}{l}\text { Natalia et al. } \\
(2017)\end{array}$ \\
\hline 7 & Peralatan (PE) & $\begin{array}{l}\text { - Kapasitas peralatan yang digunakan (PE1) } \\
\text { - Jumlah peralatan yang digunakan (PE2) } \\
\text { - Kondisi peralatan saat pelaksanaan pekerjaan (PE3) } \\
\text { - } \quad \text { Kerusakan peralatan saat pelaksanaan pekerjaan (PE4) } \\
\text { - } \quad \text { Keahlian operator masing-masing peralatan (PE6) }\end{array}$ & $\begin{array}{l}\text { Natalia et al. } \\
(2017)\end{array}$ \\
\hline 8 & $\begin{array}{l}\text { Faktor } \\
\text { Organisasi } \\
\text { (FO) }\end{array}$ & $\begin{array}{l}\text { - Dukungan dari top management (FO1) } \\
\text { - Dukungan financial (FO2) }\end{array}$ & $\begin{array}{l}\text { (Gasemagha \& } \\
\text { Kowang, 2021; Li } \\
\text { et al., 2019; } \\
\text { Maqbool \& } \\
\text { Sudong, 2018) }\end{array}$ \\
\hline
\end{tabular}


Tabel 2. Identifikasi Variabel Laten dan Variabel Indikator (lanjutan)

\begin{tabular}{|c|c|c|c|}
\hline $\mathrm{No}$ & Variabel Laten & Indikator & Sumber \\
\hline 9 & $\begin{array}{l}\text { Keberhasilan } \\
\text { Proyek (KP) }\end{array}$ & 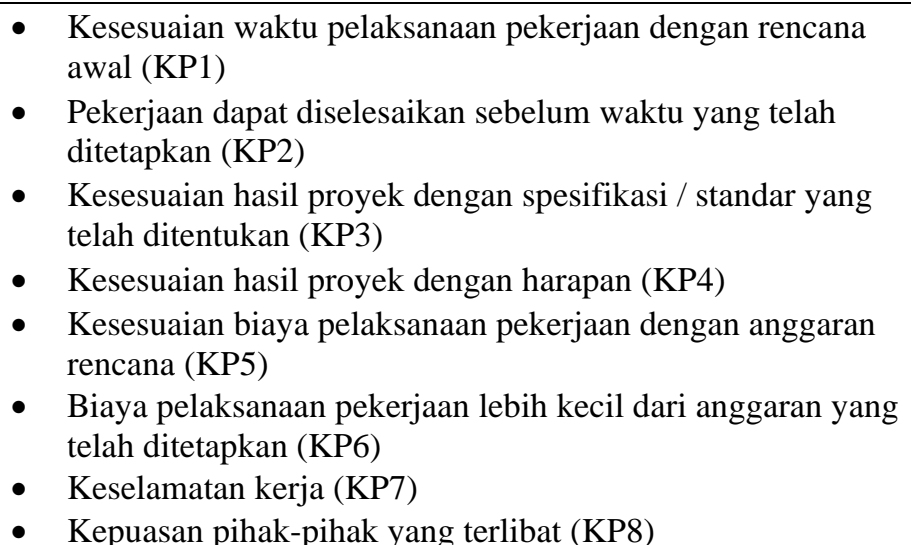 & $\begin{array}{l}\text { (Bond-Barnard et } \\
\text { al., 2018; } \\
\text { Gasemagha \& } \\
\text { Kowang, 2021; } \\
\text { Iriarte \& Bayona, } \\
\text { 2020; Li et al., } \\
\text { 2019; Machado \& } \\
\text { Martens, 2015; } \\
\text { Maqbool \& } \\
\text { Sudong, 2018; } \\
\text { Moradi et al., } \\
\text { 2020; Natalia et } \\
\text { al., 2017) }\end{array}$ \\
\hline
\end{tabular}
Sumber: Penelitian terdahulu

Catatan: Identitas variabel dan indikator seperti (MP), (PP), (FE), (MP1), (MP2), (MP3) dan lainnya digunakan untuk analisis

Variabel laten dan indikator tersebut telah diuji pada berbagai proyek namun belum dilakukan pada proyek penyusunan data desa di Indonesia. Lingkungan yang ada di desa di Indonesia memiliki karakter yang berbeda dengan industri ataupun desa yang ada di negara lain. Terdapat kesenjangan penelitian akademis terkait pengujian faktor kritis keberhasilan pada proyek penyusunan data desa presisi. Penelitian ini dapat memperkaya penelitian mengenai faktor kritis keberhasilan proyek.

Dasar dari penelitian ini, adalah untuk mempelajari faktor kritis penentu keberhasilan proyek pembangunan data desa yang akurat. Sasaran dari penelitian adalah mendapatkan jawaban dari pertanyaan penelitian sebagai berikut:

1. Apa yang menjadi faktor kritis dalam keberhasilan proyek DDP?

2. Apa faktor kritis yang memiliki dampak tertinggi pada keberhasilan proyek DDP?

3. Bagaimana tingkat pengaruh faktor kritis pada keberhasilan proyek DDP?

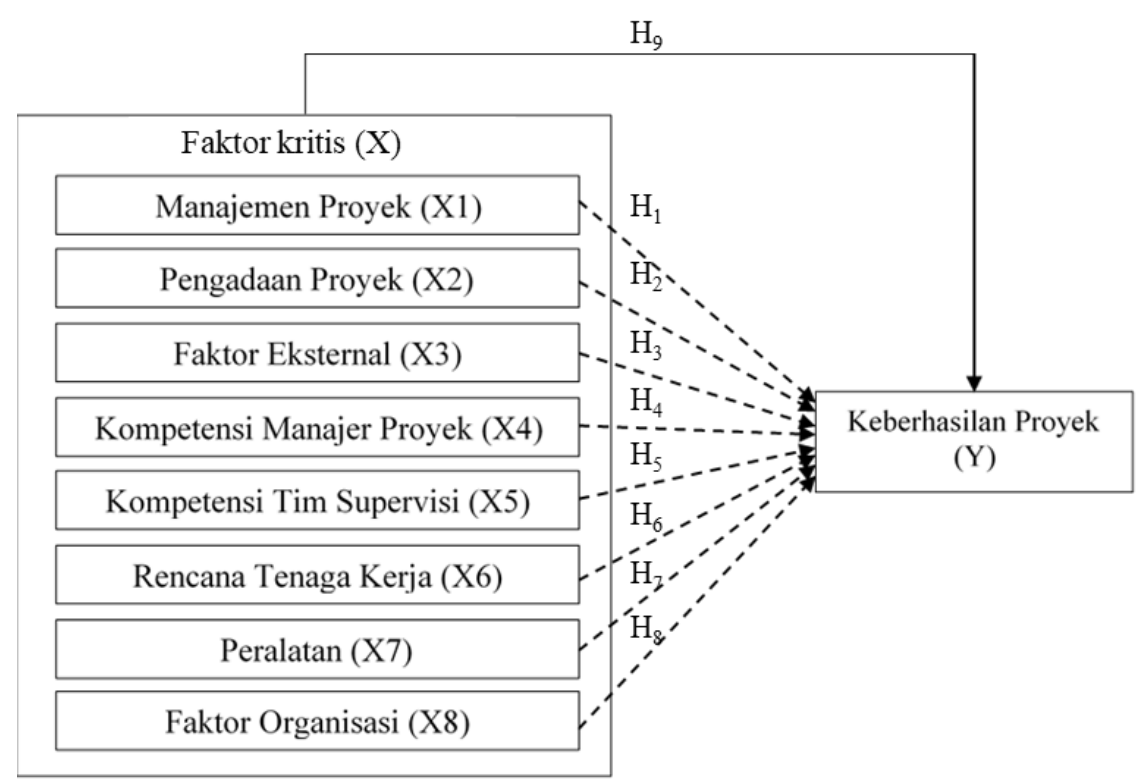

Gambar 1. Model penelitian 
Untuk menjawab pertanyaan penelitian tersebut maka disusun model penelitian seperti gambar

1. Konsisten dengan permasalahan dan kesenjangan penelitian maka artikel ini akan fokus pada analisis faktor kritis pada proyek DDP. Faktor kritis yang sudah teridentifikasi dari artikel terdahulu meliputi manajemen proyek (X1), pengadaan (X2), faktor eksternal (X3), kompetensi manajer proyek (X4), kompetensi tim supervisi (X5), rencana tenaga kerja (X6), peralatan (X7), dan faktor organisasi (X8). Faktor tersebut akan dinilai tingkat hubungannya pada keberhasilan proyek (Y) dengan indikator waktu, mutu, biaya, keselamatan kerja, dan kepuasan pihak-pihak yang terlibat. Terdapat sembilan hipotesis yang bisa disusun berdasarkan model penelitian.

Berdasarkan gambar 1, dapat uraikan hipotesis sebagai berikut:

1. Hipotesis 1 menyatakan bahwa faktor manajemen proyek mempengaruhi keberhasilan proyek DDP.

2. Hipotesis 2 menyatakan bahwa faktor pengadaan proyek mempengaruhi keberhasilan proyek DDP.

3. Hipotesis 3 menyatakan bahwa faktor eksternal mempengaruhi keberhasilan proyek DDP.

4. Hipotesis 4 menyatakan bahwa faktor kompetensi manajer proyek mempengaruhi keberhasilan proyek DDP.

5. Hipotesis 5 menyatakan bahwa faktor kompetensi tim supervisi mempengaruhi keberhasilan proyek DDP.

6. Hipotesis 6 menyatakan bahwa faktor rencana tenaga kerja memengaruhi keberhasilan proyek DDP.

7. Hipotesis 7 menyatakan bahwa faktor peralatan mempengaruhi keberhasilan proyek DDP.

8. Hipotesis 8 menyatakan bahwa faktor organisasi mempengaruhi keberhasilan proyek DDP

9. Hipotesis 9 menyatakan bahwa keseluruhan faktor mempengaruhi keberhasilan proyek secara simultan.

\section{METODE RISET}

Penelitian ini menggunakan pendekatan kuantitatif dengan metode sensus terhadap seluruh individu yang terlibat dalam proyek DDP. Data didapatkan dengan kuesioner yang berisi pertanyaan tertutup. Kuesioner diberikan kepada 141 responden yang berasal dari anggota tim proyek, pemerintah desa, dan penyaring data yang terlibat dalam Proyek DDP pada bulan Juni-Juli 2021. Kategori responden berdasarkan karakteristik peran, usia, pendidikan terakhir, pengalaman kerja, dan status pekerjaan responden dalam proyek DDP, dapat ditemukan pada Tabel 3. Penelitian dilaksanakan di enam desa yaitu Desa Sukamantri (Bogor), Desa Tegallalang (Gianyar, Bali), Desa Cihideung Ilir (Bogor), Desa Cibanteng (Bogor), Desa Gelar Anyar (Cianjur), dan Desa Bantar Jaya (Bogor).

Pengukuran variabel menggunakan skala likert, skala satu sampai lima, untuk kemudian diolah dengan perangkat lunak Smart Partial Least Square (PLS) 3.0. Skala likert yang digunakan dalam 
analisis hubungan berdasarkan nilai 1,2,3,4, dan 5 dengan penjelasan tingkatan secara berurutan adalah sangat tidak tinggi, tidak tinggi, cukup tinggi, tinggi, dan sangat tinggi. Penggunaan PLS untuk mengakomodasi keterbatasan jumlah data. Ukuran sampel minimal untuk PLS adalah 30 responden (Abdillah \& Hartono, 2015). Oleh karena itu penggunaan metoda PLS memenuhi persyaratan minimal dalam analisis tingkat dampak faktor kritis terhadap keberhasilan proyek DDP.

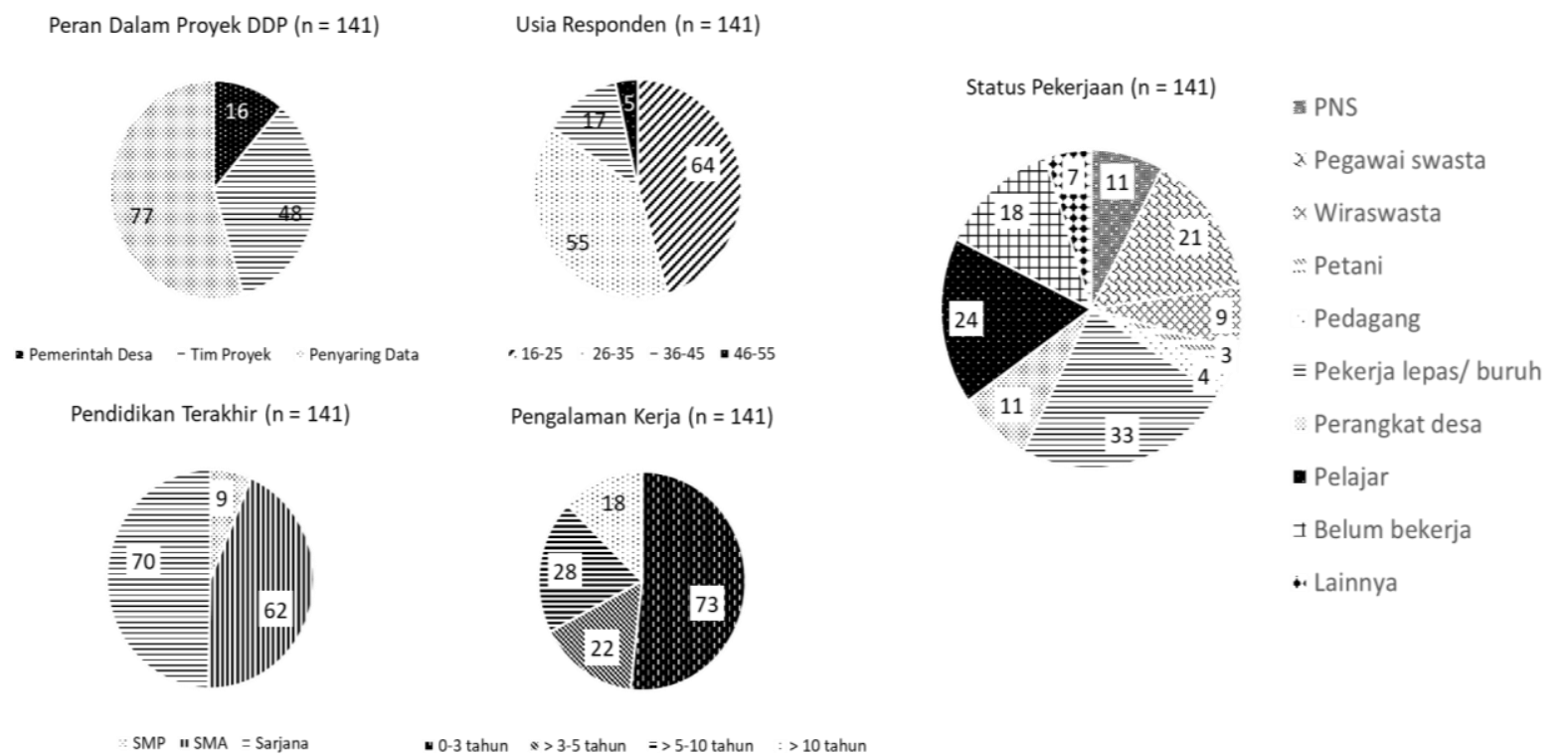

Gambar 2. Kategori responden penelitian Sumber: Data diolah, 2021

\section{HASIL PENELITIAN DAN PEMBAHASAN}

Analisis hasil kuesioner dilakukan dalam enam tahap. Tahap pertama adalah melihat pandangan responden terhadap variabel laten/faktor kritis yang akan diteliti. Tahap kedua adalah melihat pandangan responden terhadap kriteria keberhasilan proyek DDP. Tahap ketiga adalah analisis indikator dengan faktor kritis. Tahap keempat adalah analisis hubungan antar faktor kritis. Tahap kelima adalah pengujian hipotesis. Tahap keenam adalah analisis hubungan antara faktor kritis dengan kriteria keberhasilan proyek DDP.

\section{Analisis variabel laten/ faktor kritis}

Variabel laten dalam penelitian ini adalah faktor kritis yang merupakan penentu kesuksesan proyek DDP. Penelitian ini mengidentifikasi delapan faktor kritis dalam proyek DDP; yaitu manajemen proyek (X1), pengadaan proyek (X2), faktor eksternal (X3), kompetensi manajer proyek (X4), kompetensi tim supervisi (X5), rencana tenaga kerja (X6), peralatan (X7), dan faktor organisasi (X8). Hasil kuesioner menunjukan bahwa semua faktor kritis mendapat nilai cenderung sangat tinggi, di atas 4. Tabel 3 menunjukan nilai rata-rata setiap faktor kritis menurut responden.

Mayoritas responden menilai bahwa seluruh faktor kritis berpengaruh pada keberhasilan proyek DDP. Faktor manajemen proyek mendapat nilai rata-rata paling rendah. Indikator yang dipandang 
kurang berpengaruh adalah efektifitas membuat keputusan dan mengembangkan struktur organisasi. Faktor organisasi menjadi faktor kritis yang sangat penting dengan nilai rata-rata tertinggi. Indikator dari faktor organisasi adalah dukungan dari manajemen puncak dan keuangan

Tabel 3. Rata-rata Nilai Faktor Kritis

\begin{tabular}{clcl}
\hline No & \multicolumn{1}{c}{ Faktor Kritis } & Rata-rata & Kategori \\
\hline 1 & Manajemen Proyek & 4,37 & Sangat Tinggi \\
2 & Pengadaan Proyek & 4,43 & Sangat Tinggi \\
3 & Faktor Eksternal & 4,44 & Sangat Tinggi \\
4 & Kompetensi Manajer Proyek & 4,46 & Sangat Tinggi \\
5 & Kompetensi Tim Supervisi & 4,44 & Sangat Tinggi \\
6 & Rencana Tenaga Kerja & 4,14 & Sangat Tinggi \\
7 & Peralatan & 4,45 & Sangat Tinggi \\
8 & Faktor Organisasi & 4,53 & Sangat Tinggi \\
\hline
\end{tabular}

Sumber: Data diolah, 2021

\section{Analisis indikator keberhasilan proyek DDP}

Indikator yang digunakan untuk menilai keberhasilan proyek DDP dalam penelitian ini berjumlah delapan. Indikator keberhasilan proyek DDP adalah kesesuaian pelaksanaan dengan rencana proyek, pekerjaan selesai lebih cepat, kesesuaian hasil proyek dengan spesifikasi yang ditetapkan, kesesuaian hasil proyek dengan harapan, kesesuaian biaya pelaksanaan dengan anggaran proyek, biaya pelaksanaan lebih kecil dari anggaran, keselamatan kerja, dan kepuasan pihak yang terlibat dalam proyek.

Tabel 4 menunjukan rata-rata nilai ketepatan indikator terhadap kesuksesan proyek menurut responden yang terlibat dalam proyek DDP. Indikator keberhasilan proyek (Y) memiliki nilai rata-rata yang cenderung tinggi.

Tabel 3. Rataan Skor Variabel Keberhasilan Proyek Data Desa Presisi

\begin{tabular}{|c|c|c|c|}
\hline No & Indikator Keberhasilan Proyek & Rata-rata & Kategori \\
\hline 1 & $\begin{array}{l}\text { Kesesuaian waktu pelaksanaan pekerjaan dengan } \\
\text { rencana awal (KP1) }\end{array}$ & 3,97 & Tinggi \\
\hline 2 & $\begin{array}{l}\text { Pekerjaan dapat diselesaikan sebelum waktu yang } \\
\text { telah ditetapkan (KP2) }\end{array}$ & 3,89 & Tinggi \\
\hline 3 & $\begin{array}{l}\text { Kesesuaian hasil proyek dengan spesifikasi / } \\
\text { standar yang telah ditentukan (KP3) }\end{array}$ & 4,35 & Sangat Tinggi \\
\hline 4 & Kesesuaian hasil proyek dengan harapan (KP4) & 4,37 & Sangat Tinggi \\
\hline 5 & $\begin{array}{l}\text { Kesesuainan biaya pelaksanaan pekerjaan dengan } \\
\text { anggaran rencana (KP5) }\end{array}$ & 4,35 & Sangat Tinggi \\
\hline 6 & $\begin{array}{l}\text { Biaya pelaksanaan pekerjaan lebih kecil dari } \\
\text { anggaran yang telah ditetapkan (KP6) }\end{array}$ & 3,43 & Tinggi \\
\hline 7 & Keselamatan kerja (KP7) & 4,46 & Sangat Tinggi \\
\hline 8 & Kepuasan pihak-pihak yang terlibat (KP8) & 4,31 & Sangat Tinggi \\
\hline
\end{tabular}
Sumber: Data diolah, 2021

Indikator waktu pelaksanaan proyek DDP (KP1 dan KP2) kurang dipertimbangkan karena responden lebih fokus pada kualitas hasil proyek DDP. Kehadiran proyek DDP diharapkan dapat menyelesaikan masalah ketidak akuratan data yang berdampak pada kelancaran pembangunan desa. Oleh karena itu proyek DDP selalu diupayakan agar memberikan manfaat sebesar-besarnya kepada desa. Manfaat ini akan dirasakan jika hasil dari kegiatan DDP memiliki kualitas yang baik. 
Pelaksana proyek DDP perlu memastikan bahwa kegiatan pengumpulan data sesuai dengan metodologi yang sudah ditetapkan. Kepatuhan pada metodologi dapat memberikan manfaat yang maksimal pada hasil proyek. Hal tersebut dapat terwujud apabila hasil proyek DDP sesuai dengan spesifikasi/standar yang telah ditetapkan (KP3) dan juga dapat sesuai dengan harapan pemangku kepentingan (KP4).

Keselamatan kerja (KP7) dinilai responden sebagai indikator yang paling menentukan kesuksesan proyek. Proyek DDP diharapkan dapat dilakukan dengan efektif dan efisien demi menjaga tingkat keamanan dan keselamatan kerja. Penggunaan teknologi dan mekanisme kerja yang aktif berkomunikasi dengan masyarakat dirasakan membuat proses kerja semakin nyaman dan aman. Proyek DDP di tiap desa selalu diawali dengan sosialisasi dan perijinan ke berbagai pemangku kepentingan, seperti pemerintah/tokoh desa, dan aparat keamanan/Babinsa (Bintara Pembina Desa)/Babinkamtibmas (Bintara Pembina Keamanan Ketertiban Masyarakat). Proses sosialisasi sangat penting agar pelaksanaan proyek DDP bisa menghadirkan keamanan serta kenyamanan bagi setiap pihak yang terlibat. Responden juga berpendapat bahwa penerapan protokol kesehatan diperlukan pada kondisi dan lokasi tertentu, demi menjaga keselamatan seluruh pihak.

\section{Evaluasi model pengukuran (Outer Model)}

Analisis outer model merupakan hubungan antara variabel laten dengan indikatornya. Dalam penelitian ini outer model menggambarkan tingkat hubungan antara faktor kritis dengan indikator pembentuknya. Analisis ini dilakukan sebagai upaya untuk memastikan ketepatan dan keandalan indikator sebagai elemen pengukuran. Analisis outer model memiliki tiga pengujian, yaitu convergent validity, discriminant validity, dan composite reliability. Convergent validity dan discriminant validity digunakan untuk menguji validitas sementara composite reliability digunakan untuk menguji reliabilitas.

Hasil pengujian convergent validity menunjukkan nilai outer loading lebih besar dari 0,70 untuk semua indikator. Aturan praktis atau rule of thumb untuk memenuhi validitas adalah apabila outer loading > 0,70 (Wong, 2013). Gambar 2 memperlihatkan bahwa nilai paling rendah pengujian indikator adalah 0,709. Dengan hasil tersebut maka model dikatakan sudah memenuhi kriteria convergent validity dan selanjutnya dapat diuji dengan discriminant validity.

Discriminant Validity dapat dihitung dengan mempertimbangkan nilai cross loading indikator terhadap variabel laten. Apabila nilai korelasi antara variabel laten dengan setiap indikator lebih besar daripada korelasi dengan variabel laten lainnya, maka variabel laten tersebut mampu memprediksi indikatornya lebih baik daripada variabel laten lainnya (Zait \& Bertea, 2011). Tabel 4 menunjukkan hasil uji discriminant validity berupa nilai cross loading tiap faktor kritis dan keberhasilan proyek. Tiap indikator telah teralokasikan sesuai dengan nilai cross loading paling besar pada masing-masing faktor kritis maupun keberhasilan proyek. Hasil tersebut menunjukan bahwa uji discriminant validity telah memenuhi syarat dan dapat dilanjutkan kepada uji reliabilitas, composite reliability. 


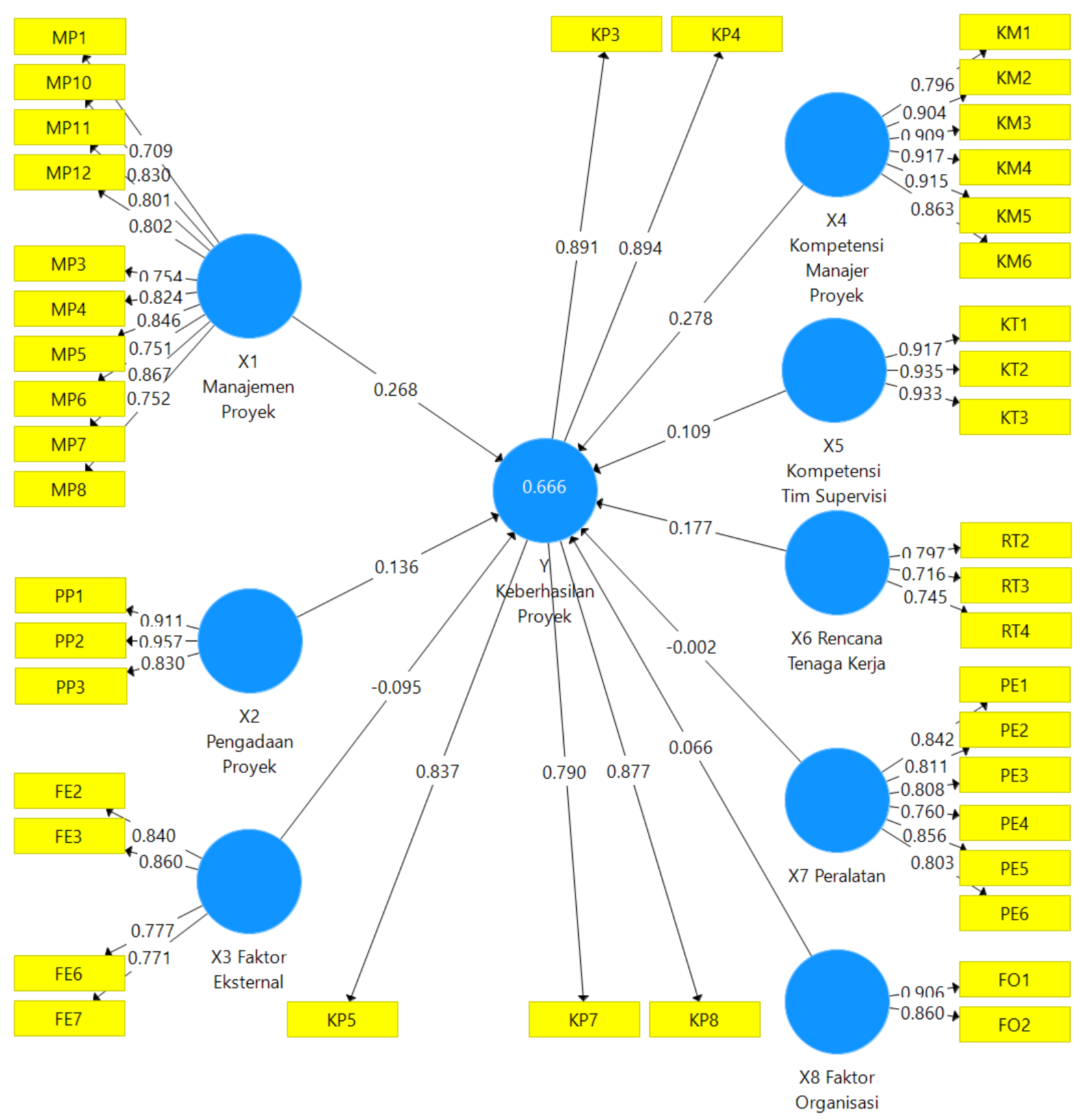

Gambar 2. Hasil Uji Convergent Validity pada SmartPLS 3.0. Sumber: Data diolah, 2021

Composite Reliability (CR) digunakan untuk memastikan adanya konsistensi nilai hubungan variabel dengan indikator pembentuknya (internal consistency). Variabel dinyatakan dapat digunakan jika nilai composite reliability di atas 0,70 (Hair et al., 2017). Dalam penelitian ini variabel yang diuji adalah faktor kritis dan keberhasilan proyek. Berdasarkan analisis, semua faktor kritis dan keberhasilan proyek telah memenuhi syarat karena nilai CR lebih besar dari 0,70 . Sehingga faktor kritis dan keberhasilan proyek dan indikator pembentuknya sudah sesuai untuk menjawab pertanyaan penelitian. Nilai composite reliability pada penelitian ini dapat dilihat pada tabel 5. 
Mulyoningtyas, R.R. \& Handaka, A.W. .(2022). Analisis Pengaruh Faktor Kritis ....

Tabel 4. Uji Discriminant Validity pada SmartPLS 3.0.

$\begin{array}{ccccccccc}\text { X1 } & & & \text { X4 } & \text { X5 } & \text { X6 } & & \text { X8 } & \text { Y } \\ \text { Manajem } & \text { X2 } & \text { X3 } & \text { Kompete } & \text { Kompete } & \text { Rencana } & \text { X7 } & \text { Faktor } & \text { Keberhas } \\ \text { en } & \text { Pengadaa } & \text { Faktor } & \text { nsi } & \text { nsi Tim } & \text { Tenaga } & \text { Peralatan } & \text { Organisa } & \text { ilan } \\ \text { Proyek } & \text { n Proyek } & \text { Eksternal } & \begin{array}{c}\text { Manajer } \\ \text { Proyek }\end{array} & \text { Supervisi } & \text { Kerja } & & \text { si } & \text { Proyel }\end{array}$

\begin{tabular}{|c|c|c|c|c|c|c|c|c|c|}
\hline FE2 & 0,636 & 0,528 & 0,840 & 0,587 & 0,565 & 0,409 & 0,606 & 0,600 & 0,531 \\
\hline FE3 & 0,670 & 0,602 & 0,860 & 0,649 & 0,640 & 0,483 & 0,650 & 0,624 & 0,537 \\
\hline FE6 & 0,472 & 0,384 & 0,777 & 0,505 & 0,497 & 0,479 & 0,637 & 0,495 & 0,393 \\
\hline FE7 & 0,523 & 0,411 & 0,771 & 0,543 & 0,429 & 0,424 & 0,611 & 0,485 & 0,432 \\
\hline FO1 & 0,633 & 0,585 & 0,700 & 0,626 & 0,642 & 0,462 & 0,694 & 0,906 & 0,545 \\
\hline $\mathrm{FO} 2$ & 0,400 & 0,305 & 0,492 & 0,471 & 0,532 & 0,433 & 0,572 & 0,860 & 0,451 \\
\hline KM1 & 0,534 & 0,537 & 0,582 & 0,796 & 0,678 & 0,564 & 0,570 & 0,474 & 0,586 \\
\hline KM2 & 0,689 & 0,673 & 0,665 & 0,904 & 0,775 & 0,534 & 0,622 & 0,583 & 0,652 \\
\hline KM3 & 0,667 & 0,680 & 0,600 & 0,909 & 0,770 & 0,533 & 0,569 & 0,533 & 0,702 \\
\hline KM4 & 0,666 & 0,688 & 0,649 & 0,917 & 0,748 & 0,450 & 0,579 & 0,530 & 0,652 \\
\hline KM5 & 0,704 & 0,716 & 0,629 & 0,915 & 0,790 & 0,531 & 0,665 & 0,589 & 0,709 \\
\hline KM6 & 0,675 & 0,635 & 0,634 & 0,863 & 0,767 & 0,448 & 0,649 & 0,618 & 0,656 \\
\hline KP3 & 0,693 & 0,604 & 0,474 & 0,713 & 0,704 & 0,522 & 0,548 & 0,519 & 0,891 \\
\hline KP4 & 0,647 & 0,585 & 0,480 & 0,602 & 0,622 & 0,495 & 0,515 & 0,473 & 0,894 \\
\hline KP5 & 0,543 & 0,588 & 0,497 & 0,643 & 0,592 & 0,529 & 0,524 & 0,421 & 0,837 \\
\hline KP7 & 0,648 & 0,637 & 0,624 & 0,599 & 0,603 & 0,513 & 0,569 & 0,535 & 0,790 \\
\hline KP8 & 0,615 & 0,574 & 0,460 & 0,640 & 0,603 & 0,523 & 0,508 & 0,484 & 0,877 \\
\hline KT1 & 0,697 & 0,615 & 0,636 & 0,779 & 0,917 & 0,619 & 0,709 & 0,638 & 0,670 \\
\hline KT2 & 0,671 & 0,676 & 0,620 & 0,777 & 0,935 & 0,599 & 0,670 & 0,610 & 0,679 \\
\hline KT3 & 0,669 & 0,638 & 0,590 & 0,820 & 0,933 & 0,563 & 0,663 & 0,614 & 0,684 \\
\hline MP1 & 0,709 & 0,514 & 0,327 & 0,426 & 0,535 & 0,399 & 0,385 & 0,407 & 0,502 \\
\hline MP10 & 0,830 & 0,698 & 0,628 & 0,608 & 0,613 & 0,481 & 0,581 & 0,501 & 0,586 \\
\hline MP11 & 0,801 & 0,664 & 0,677 & 0,568 & 0,536 & 0,445 & 0,538 & 0,466 & 0,636 \\
\hline MP12 & 0,802 & 0,702 & 0,638 & 0,636 & 0,660 & 0,512 & 0,582 & 0,547 & 0,644 \\
\hline MP3 & 0,754 & 0,587 & 0,522 & 0,542 & 0,614 & 0,478 & 0,563 & 0,459 & 0,569 \\
\hline MP4 & 0,824 & 0,648 & 0,575 & 0,599 & 0,583 & 0,432 & 0,496 & 0,441 & 0,551 \\
\hline MP5 & 0,846 & 0,657 & 0,520 & 0,645 & 0,624 & 0,512 & 0,543 & 0,436 & 0,643 \\
\hline MP6 & 0,751 & 0,651 & 0,593 & 0,689 & 0,599 & 0,344 & 0,470 & 0,452 & 0,521 \\
\hline MP7 & 0,867 & 0,696 & 0,651 & 0,639 & 0,567 & 0,377 & 0,619 & 0,536 & 0,635 \\
\hline MP8 & 0,752 & 0,645 & 0,530 & 0,541 & 0,472 & 0,459 & 0,574 & 0,483 & 0,524 \\
\hline PE1 & 0,484 & 0,370 & 0,562 & 0,476 & 0,567 & 0,549 & 0,842 & 0,583 & 0,455 \\
\hline PE2 & 0,473 & 0,342 & 0,510 & 0,495 & 0,572 & 0,614 & 0,811 & 0,534 & 0,488 \\
\hline PE3 & 0,527 & 0,452 & 0,638 & 0,589 & 0,625 & 0,598 & 0,808 & 0,560 & 0,513 \\
\hline PE4 & 0,544 & 0,428 & 0,662 & 0,525 & 0,529 & 0,470 & 0,760 & 0,551 & 0,448 \\
\hline PE5 & 0,591 & 0,443 & 0,615 & 0,538 & 0,651 & 0,585 & 0,856 & 0,560 & 0,517 \\
\hline PE6 & 0,655 & 0,591 & 0,731 & 0,701 & 0,697 & 0,505 & 0,803 & 0,709 & 0,584 \\
\hline PP1 & 0,703 & 0,911 & 0,449 & 0,704 & 0,629 & 0,457 & 0,450 & 0,444 & 0,660 \\
\hline PP2 & 0,733 & 0,957 & 0,539 & 0,695 & 0,643 & 0,440 & 0,474 & 0,446 & 0,663 \\
\hline PP3 & 0,780 & 0,830 & 0,666 & 0,603 & 0,601 & 0,372 & 0,567 & 0,521 & 0,553 \\
\hline RT2 & 0,332 & 0,228 & 0,322 & 0,324 & 0,345 & 0,797 & 0,440 & 0,230 & 0,387 \\
\hline RT3 & 0,239 & 0,195 & 0,172 & 0,243 & 0,293 & 0,716 & 0,279 & 0,119 & 0,364 \\
\hline RT4 & 0,603 & 0,547 & 0,634 & 0,633 & 0,699 & 0,745 & 0,716 & 0,658 & 0,556 \\
\hline
\end{tabular}

Sumber: Data diolah, 2021 
Tabel 5. Nilai Composite Reliablity Program SmartPLS 3.0. (2021)

\begin{tabular}{lcc}
\hline & Composite Reliablity & Keterangan \\
\hline X1 Manajemen Proyek & 0,945 & Reliabel \\
X2 Pengadaan Proyek & 0,928 & Reliabel \\
X3 Faktor Eksternal & 0,886 & Reliabel \\
X4 Kompetensi Manajer Proyek & 0,956 & Reliabel \\
X5 Kompetensi Tim Supervisi & 0,949 & Reliabel \\
X6 Rencana Tenaga Kerja & 0,797 & Reliabel \\
X7 Peralatan & 0,922 & Reliabel \\
X8 Faktor Organisasi & 0,877 & Reliabel \\
Y Keberhasilan Proyek & 0,933 & Reliabel \\
\hline \multicolumn{2}{c}{ Sumber: Data diolah, 2021} \\
\end{tabular}

\section{Evaluasi Model Struktural (Inner Model)}

Model struktural (Inner model) merupakan model yang digunakan untuk melihat adanya hubungan sebab-akibat antar variabel laten atau variabel yang tidak dapat diukur secara langsung. Pengujian model struktural pada variabel dependen dapat menggunakan parameter $\mathrm{R}^{2}$ ( $R$-Square) (Sekaran \& Bougie, 2020). Semakin besar nilai $\mathrm{R}^{2}$ maka model penelitian yang diajukan memiliki tingkat penerimaan yang semakin baik (Abdillah, 2018). Nilai $\mathrm{R}^{2}$ dapat mendefinisikan hubungan sebab-akibat yang kuat, moderat, dan lemah dengan nilai yang berturutan sebesar 0.67, 0.33, dan 0.19 (Ghozali \& Latan, 2015).

Tabel 6. Nilai $\mathbf{R}^{2}$ Program SmartPLS 3.0.

\begin{tabular}{cc} 
& \multicolumn{2}{c}{$R$ Square } \\
\hline Y Keberhasilan Proyek & 0,67 \\
\hline \multicolumn{2}{c}{ Sumber: Data diolah, 2021}
\end{tabular}

Nilai R2 pada penelitian ini, yang diuji dengan program SmartPLS 3.0., adalah 0,67 seperti ditunjukan pada tabel 6. Nilai tersebut memperlihatkan bahwa variabel dependen atau keberhasilan proyek memberikan hubungan sebab-akibat dengan faktor kritis penentu keberhasilan proyek DDP.

\section{Pengujian Hipotesis}

Penelitian ini memiliki 9 hipotesis yang disusun untuk menguji pengaruh tiap faktor kritis pada keberhasilan proyek secara parsial (uji signifikansi parameter individual). Pengujian tersebut menggunakan uji-t, dan selanjutnya menguji pengaruh keseluruhan faktor kritis terhadap keberhasilan proyek secara bersamaan dengan uji-F (uji signifikansi simultan).

Pengujian hipotesis uji-t dilakukan dengan metode bootstrapping untuk melihat nilai original sample, sample mean, standard deviation, $t$-statistic dan $p$-value. Pengaruh dan signifikan yang terjadi antar faktor kritis dan keberhasilan proyek ditunjukkan oleh nilai $t$-statistic atau $p$-value. Metode ini dapat memunculkan signifikansi statistik model penelitian melalui penguji hipotesis tiap jalur hubungan. Nilai koefisien dari model dikatakan signifikan jika nilai $t$-statistic $>$ t-tabel yakni sebesar 1,656 (1,656 adalah nilai t-tabel dalam tingkat keyakinan 90\%, level signifikansi $10 \%$, df $=\mathrm{n}-\mathrm{k})$. Penggunaan level signifikansi $10 \%$ berdasarkan kondisi keterbatasan jumlah dan heterogenitas responden. Tabel 7 menunjukkan koefisien untuk tiap jalur hipotesis dan nilai $t$-statistic yang diperoleh menggunakan kalkulasi bootstrapping. 
Tabel 7. Uji-T Pengaruh Faktor Kritis pada Keberhasilan Proyek

\begin{tabular}{lccccc}
\hline & $\begin{array}{c}\text { Original } \\
\text { Sample (O) }\end{array}$ & $\begin{array}{c}\text { Sample } \\
\text { Mean (M) }\end{array}$ & $\begin{array}{c}\text { Standard } \\
\text { Deviation } \\
(\text { STDEV) }\end{array}$ & $\begin{array}{c}\text { T Statistic } \\
(\mid \text { OSTDEV|) }\end{array}$ & $\begin{array}{c}p \text { - } \\
\text { Values }\end{array}$ \\
\hline $\begin{array}{l}\text { X1 Manajemen Proyek -> Y } \\
\begin{array}{l}\text { Keberhasilan Proyek } \\
\text { X2 Pengadaan Proyek -> Y }\end{array}\end{array}$ & 0,268 & 0,289 & 0,147 & 1,832 & 0,068 \\
$\begin{array}{l}\text { Keberhasilan Proyek } \\
\text { X3 Faktor Eksternal -> Y }\end{array}$ & 0,136 & 0,137 & 0,114 & 1,190 & 0,235 \\
$\begin{array}{l}\text { Keberhasilan Proyek } \\
\text { X4 Kompetensi Manajer Proyek -> }\end{array}$ & $-0,095$ & $-0,084$ & 0,096 & 0,993 & 0,321 \\
$\begin{array}{l}\text { Y Keberhasilan Proyek } \\
\text { X5Kompetensi Tim Supervisi -> Y }\end{array}$ & 0,278 & 0,238 & 0,185 & 1,502 & 0,134 \\
$\begin{array}{l}\text { Keberhasilan Proyek } \\
\text { X6 Rencana Tenaga Kerja -> Y }\end{array}$ & 0,109 & 0,128 & 0,148 & 0,737 & 0,461 \\
$\begin{array}{l}\text { Keberhasilan Proyek } \\
\text { X7 Peralatan -> Y Keberhasilan }\end{array}$ & 0,177 & 0,168 & 0,087 & 2,039 & 0,042 \\
$\begin{array}{l}\text { Proyek } \\
\text { X8 Faktor Organisasi -> Y }\end{array}$ & $-0,002$ & 0,010 & 0,105 & 0,021 & 0,984 \\
Keberhasilan Proyek & 0,066 & 0060, & 0,102 & 0,650 & 0,516 \\
\hline
\end{tabular}

Sumber: Data diolah, 2021

Berdasarkan hasil uji-t pada program SmartPLS 3.0. maka dapat diperoleh penilaian pada hipotesis sebagai berikut:

\section{Hipotesis 1: Pengaruh manajemen proyek terhadap keberhasilan proyek}

Hipotesis 1 menyatakan bahwa manajemen proyek memberikan pengaruh pada keberhasilan proyek DDP secara parsial. Hasil pengujian menunjukkan nilai t-statistic sebesar 1,832 dan lebih besar dari t-tabel $(1,656)$. Sehingga dapat disimpulkan bahwa faktor kritis manajemen proyek berpengaruh positif dan signifikan terhadap keberhasilan proyek DDP secara parsial (Hipotesis 1 diterima).

\section{Hipotesis 2: Pengaruh pengadaan proyek terhadap keberhasilan proyek}

Hipotesis 2 menyatakan bahwa pengadaan proyek memberikan pengaruh pada keberhasilan proyek DDP secara parsial. Hasil pengujian hipotesis menunjukkan nilai $t$-statistic sebesar 1,190 lebih kecil dari t-tabel. Sehingga dapat disimpulkan bahwa faktor kritis pengadaan proyek tidak berpengaruh signifikan terhadap keberhasilan proyek DDP secara parsial (Hipotesis 2 ditolak).

\section{Hipotesis 3: Pengaruh faktor eksternal terhadap keberhasilan proyek}

Hipotesis 3 menyatakan bahwa faktor eksternal memberikan pengaruh pada keberhasilan proyek DDP secara parsial. Hasil pengujian hipotesis menunjukkan nilai $t$-statistic sebesar 0,993 lebih kecil dari t-tabel. Sehingga faktor kritis eksternal tidak berpengaruh signifikan terhadap keberhasilan proyek DDP secara parsial (Hipotesis 3 ditolak).

\section{Hipotesis 4: Pengaruh kompetensi manajer proyek terhadap keberhasilan proyek}

Hipotesis 4 menyatakan bahwa kompetensi manajer proyek memberikan pengaruh pada keberhasilan proyek DDP secara parsial. Hasil pengujian hipotesis menunjukkan nilai $t$-statistic sebesar 1,502 lebih kecil dari t-tabel. Sehingga faktor kritis kompetensi manajer proyek tidak berpengaruh signifikan terhadap keberhasilan proyek DDP secara parsial (Hipotesis 4 ditolak). 


\section{Hipotesis 5: Pengaruh kompetensi tim supervisi terhadap keberhasilan proyek}

Hipotesis 5 menyatakan bahwa kompetensi tim supervisi memberikan pengaruh pada keberhasilan proyek DDP secara parsial. Hasil pengujian hipotesis menunjukkan nilai $t$-statistic sebesar 0,737 lebih kecil dari t-tabel. Sehingga faktor kritis kompetensi tim supervisi tidak berpengaruh signifikan terhadap keberhasilan proyek DDP secara parsial (Hipotesis 5 ditolak).

\section{Hipotesis 6: Pengaruh rencana tenaga kerja terhadap keberhasilan proyek}

Hipotesis 6 menyatakan bahwa rencana tenaga kerja memberikan pengaruh pada keberhasilan proyek DDP secara parsial. Hasil pengujian hipotesis menunjukkan nilai $t$-statistic sebesar 2,039 lebih besar dari t-tabel. Sehingga faktor kritis rencana tenaga kerja berpengaruh positif dan signifikan terhadap keberhasilan proyek DDP secara parsial (Hipotesis 6 diterima).

\section{Hipotesis 7: Pengaruh peralatan terhadap keberhasilan proyek}

Hipotesis 7 menyatakan bahwa peralatan memberikan pengaruh pada keberhasilan proyek DDP secara parsial. Hasil pengujian hipotesis menunjukkan nilai $t$-statistic sebesar 0,021 lebih kecil dari ttabel. Sehingga faktor kritis peralatan tidak berpengaruh signifikan terhadap keberhasilan proyek DDP secara parsial (Hipotesis 7 ditolak).

\section{Hipotesis 8: Pengaruh faktor organisasi terhadap keberhasilan proyek}

Hipotesis 8 menyatakan bahwa faktor organisasi memberikan pengaruh pada keberhasilan proyek DDP secara parsial. Hasil pengujian hipotesis menunjukkan nilai $t$-statistic sebesar 0,650 lebih kecil dari t-tabel. Sehingga faktor kritis organisasi tidak berpengaruh signifikan terhadap keberhasilan proyek DDP secara parsial (Hipotesis 8 ditolak).

Setelah menguji delapan hipotesis, selanjutnya melakukan pengujian pengaruh keseluruhan faktor kritis pada keberhasilan proyek. Pengujian menggunakan uji F (uji signifikansi simultan). Nilai koefisien dari model dikatakan signifikan jika nilai f-hitung > f-tabel yakni sebesar 2,009 (2,009 adalah nilai f-tabel dalam tingkat keyakinan $95 \%$, level signifikansi $5 \%$, df = 8;132). Nilai f-hitung didapatkan dengan menggunakan persamaan (1).

$$
F=\frac{\frac{R^{2}}{(k-1)}}{\frac{\left(1-R^{2}\right)}{(n-k)}}
$$

\section{Keterangan:}

$\mathrm{R}^{2}$ : koefisien determinasi

$\mathrm{n}$ : jumlah data

$\mathrm{k}$ : jumlah variabel

Melalui persamaan (1) maka diperoleh nilai f-hitung sebesar 32,901. Berdasarkan nilai tersebut maka hipotesis sembilan dapat ditetapkan. 


\section{Hipotesis 9: Pengaruh keseluruhan faktor kritis pada keberhasilan proyek}

Hipotesis 9 menyatakan bahwa keseluruhan faktor kritis memberikan pengaruh pada keberhasilan proyek secara simultan. Hasil pengujian hipotesis menunjukkan nilai f-hitung $(32,901)$ lebih besar dari f-tabel $(2,009)$. Sehingga keseluruhan faktor kritis berpengaruh positif dan signifikan pada keberhasilan proyek DDP secara simultan (Hipotesis 9 diterima).

Meskipun keseluruhan faktor kritis berpengaruh signifikan pada keberhasilan proyek DDP secara bersamaan, namun pengujian secara parsial hanya menerima faktor kritis manajemen proyek dan rencana tenaga kerja. Hal tersebut dapat dipahami bahwa responden hanya melihat dan merasakan proyek DDP sebagai sebuah kegiatan pendataan dengan jumlah orang yang tidak sedikit. Tenaga kerja yang terlibat di dalamnya memiliki beragam latar pendidikan, pekerjaan dan keterampilan. Oleh karena itu responden merasa bahwa manajemen proyek diperlukan secara nyata dalam pengelolaan tenaga kerja yang bervariasi. Responden juga melihat pentingnya rencana tenaga kerja sehingga proyek DDP dapat berjalan dengan lancar. Ketika faktor kritis diuji secara bersamaan, dapat dilihat bahwa sesungguhnya faktor kritis akan saling terkait dan mendukung satu dengan lainnya.

\section{Pengaruh Faktor Kritis Pada Keberhasilan Proyek DDP}

Hasil analisis dengan SmartPLS 3.0. menunjukkan bahwa keberhasilan proyek DDP dipengaruhi secara positif dan signifikan oleh manajemen proyek dan rencana tenaga kerja. Berdasarkan hasil kalkulasi bootstrapping, terdapat 10 sub faktor kritis manajemen proyek dan tiga sub faktor kritis rencana tenaga kerja. Lima sub faktor kritis manajemen proyek yang berpengaruh signifikan pada keberhasilan proyek DDP adalah MP7 (implementasi program penjaminan mutu yang efektif), MP5 (monitoring proyek), MP10 (identifikasi dan alokasi risiko), MP11 (komitmen semua pihak yang terlibat pada proyek), dan MP12 (tujuan dan sasaran yang jelas). Sementara sub faktor kritis rencana tenaga kerja yang berpengaruh signifikan pada keberhasilan proyek DDP, secara berurutan, adalah RT2 (keahlian tenaga kerja berdasarkan pengalaman), RT4 (produktivitas tenaga kerja), dan RT3 (keahlian tenaga kerja berdasarkan tingkat Pendidikan), dapat dilihat pada Gambar 3.

Rencana tenaga kerja merupakan faktor kritis yang berpengaruh signifikan dan berdampak tinggi pada keberhasilan proyek DDP, dibandingkan manajemen proyek. Tabel 7 menunjukan bahwa nilai $t$-statistic rencana tenaga kerja $(2,039)$ lebih besar dari manajemen proyek $(1,832)$. Hasil tersebut dapat dipahami karena pelaksanaan proyek DDP membutuhkan jumlah tenaga kerja yang relatif banyak. Proyek DDP di satu desa akan melibatkan tenaga kerja berkisar antara 30-50 orang dengan beragam latar pendidikan, pekerjaan dan keterampilan. Hal ini yang menjadikan pandangan pentingnya rencana tenaga kerja dan manajemen proyek.

Lebih jauh lagi, manajemen proyek dalam kegiatan DDP menjadi semacam prosesor dan rencana tenaga kerja menjadi mesin penggerak dalam menjalankan proyek DDP. Kelancaran proyek DDP membutuhkan pola komunikasi antar pihak-pihak yang terlibat. Pelaksanaan proyek DDP 
memunculkan beberapa kendala dan perlu tindakan cepat dari penyaring data, tim proyek, dan pemerintah desa.

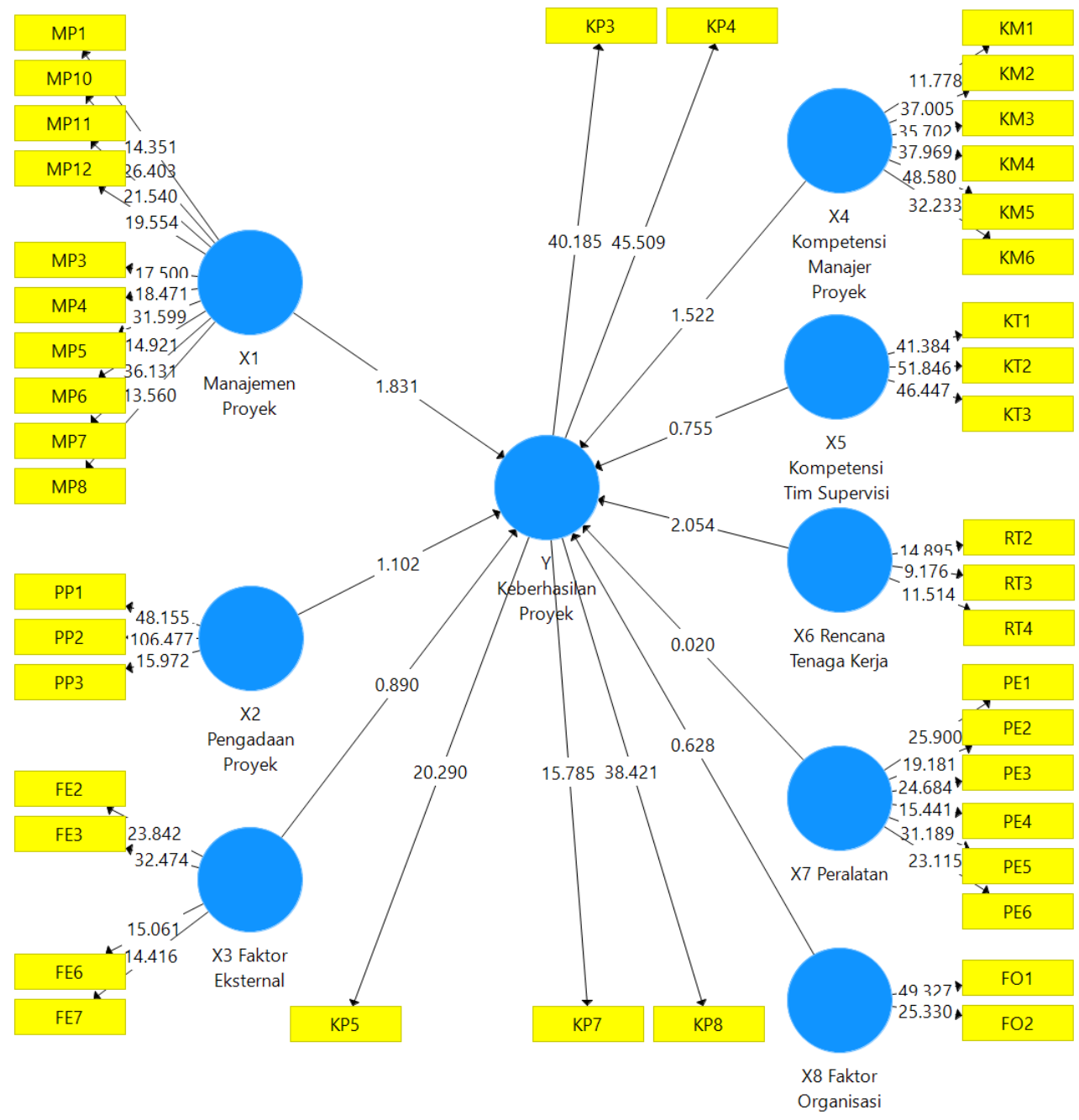

Gambar 3. Hasil Kalkulasi Bootstrapping

Sumber: Data diolah, 2021

\section{KESIMPULAN DAN SARAN}

Kesimpulan yang bisa diperoleh dari penelitian ini adalah:

1. Implementasi program penjaminan mutu yang efektif, monitoring proyek, identifikasi dan alokasi risiko, komitmen semua pihak yang terlibat pada proyek, dan tujuan dan sasaran yang jelas merupakan sub faktor kritis manajemen proyek yang berpengaruh signifikan terhadap keberhasilan proyek DDP. Sedangkan keahlian tenaga kerja, produktivitas tenaga kerja, dan keahlian tenaga kerja merupakan sub faktor kritis rencana tenaga kerja yang memiliki pengaruh signifikan pada keberhasilan proyek DDP.

2. Rencana tenaga kerja merupakan faktor kritis yang paling berpengaruh dan memiliki dampak tertinggi terhadap keberhasilan proyek DDP dengan sub faktornya keahlian tenaga kerja.

3. Pengadaan proyek, faktor eksternal, kompetensi manajer proyek, kompetensi tim supervisi, peralatan, dan faktor organisasi dipandang tidak berpengaruh signifikan secara parsial terhadap 
keberhasilan proyek DDP. Namun seluruh faktor kritis dapat berpengaruh positif dan signifikan terhadap keberhasilan proyek DDP secara simultan. Secara bersama-sama manajemen proyek, pengadaan proyek, faktor eksternal, kompetensi manajer proyek, kompetensi tim supervisi, rencana tenaga kerja, peralatan, dan faktor organisasi mampu memberikan pengaruh terhadap keberhasilan proyek sebesar $67 \%$.

Hasil penelitian ini sejalan dengan penelitian-penelitian terdahulu yang menyarankan komitmen sebagai faktor kritis penentu keberhasilan proyek (Li et al., 2019; Natalia et al., 2017; Zachawerus \& Soekiman, 2018). Proyek DDP juga perlu mengelola, terutama, komitmen dari pihak yang terlibat dalam pelaksanaan proyek. Lebih jauh lagi, tujuan dan sasaran juga perlu dikomunikasikan dengan pihak yang terlibat dalam proyek DDP.

Saran untuk penelitian lanjutan adalah memasukan keragaman tingkat pendidikan masyarakat desa serta karakter tiap desa sebagai faktor kritis penentu keberhasilan proyek DDP. Ragam pendidikan dapat membentuk perilaku serta komitmen pihak yang terlibat dalam proyek DDP. Semakin tinggi tingkat pendidikan akan semakin mudah untuk melakukan koordinasi demi kelancaran proyek DDP. Semakin tinggi tingkat pendidikan penduduk suatu desa maka akan mempermudah pembentukan karakter suatu desa. 


\section{DAFTAR PUSTAKA}

Abdillah, W. (2018). Metode Penelitian Terpadu Sistem Informasi : Permodelan Teoritis, Pengukuran dan Pengujian Statistis (Ed. 1). ANDI.

Abdillah, W., \& Hartono, J. (2015). Partial Least Square (PLS) : Alternatif Structural Equation Modeling (SEM) dalam Penelitian Bisnis (D. Prabantini (ed.); Ed. 1). ANDI.

Bond-Barnard, T. J., Fletcher, L., \& Steyn, H. (2018). Linking trust and collaboration in project teams to project management success. International Journal of Managing Projects in Business, 11(2), 432-457. https://doi.org/10.1108/IJMPB-06-2017-0068

Gasemagha, A. A., \& Kowang, T. O. (2021). Project Manager Role in Project Management Success. International Journal of Academic Research in Business and Social Sciences, 11(3), 1345-1355. https://doi.org/10.6007/ijarbss/v11-i3/9230

Ghozali, I., \& Latan, H. (2015). Partial Least Square Konsep Teknik dan Aplikasi Menggunakan Program SmartPLS 3.0. In Universitas Diponegoro (2nd ed.).

Hair, J., Hollingsworth, C. L., Randolph, A. B., \& Chong, A. Y. L. (2017). An updated and expanded assessment of PLS-SEM in information systems research. Industrial Management and Data Systems, 117(3), 442-458. https://doi.org/10.1108/IMDS-04-2016-0130

Iriarte, C., \& Bayona, S. (2020). It projects success factors: A literature review. International Journal of Information Systems and Project Management, 8(2), 49-78. https://doi.org/10.12821/ijispm080203

Jitpaiboon, T., Smith, S. M., \& Gu, Q. (2019). Critical Success Factors Affecting Project Performance: An Analysis of Tools, Practices, and Managerial Support Thawatchai. Project Management Journal, 50(3), 271-287. https://doi.org/10.1177/8756972819833545

Kemendes. (2020). Profiling Eksisting Desa Tertinggal Dan Sangat Tertinggal Dan Lokasi Pengentasan 2020-2024.

Kementerian Keuangan. (2018). Akumulasi Penyaluran Dana Desa Hingga Tahun 2018 Tahap 2 Mencapai Rp149,31 Triliun. Www.Kemenkeu.Go.Id. https://www.kemenkeu.go.id/publikasi/berita/akumulasi-penyaluran-dana-desa-hingga-tahun2018-tahap-2-mencapai-rp149-31-triliun/

Kerzner, H. (2017). Project Management A Systems Approach To Planning, Scheduling, and Controlling (Twelfth Ed). John Wiley \& Sons, Inc.

Li, Y., Song, H., Sang, P., Chen, P. H., \& Liu, X. (2019). Review of Critical Success Factors (CSFs) for green building projects. Building and Environment, 158(January), 182-191. https://doi.org/10.1016/j.buildenv.2019.05.020 
Machado, F. J., \& Martens, C. D. P. (2015). Project Management Success: A Bibliometric Analisys. Revista de Gestão e Projetos, 06(01), 28-44. https://doi.org/10.5585/gep.v6i1.310

Maqbool, R., \& Sudong, Y. (2018). Critical success factors for renewable energy projects; empirical evidence from Pakistan. Journal of Cleaner Production, 195, 991-1002. https://doi.org/10.1016/j.jclepro.2018.05.274

Moradi, S., Kähkönen, K., \& Aaltonen, K. (2020). From past to present - the development of project success research. Journal of Modern Project Management, 8(1), 1-20. https://doi.org/10.19255/JMPM02301

Natalia, M., Partawijaya, Y., . M., \& . S. (2017). Analisis Critical Success Factors Proyek Konstruksi Di Kota Padang. Jurnal Fondasi, 6(2). https://doi.org/10.36055/jft.v6i2.2632

Sekaran, U., \& Bougie, R. (2020). Research methods for business: A Skill Building Approach (J. Marshall (ed.); 8th ed.). Hoboken: Wiley.

Sjaf, S., Elson, L., Hakim, L., \& Godya, I. M. (2020). Data Desa Presisi (B. Muhammad (ed.); Ed. 1). IPB Press.

Wong, K. K. K.-K. (2013). Partial Least Squares Structural Equation Modeling (PLS-SEM) Techniques Using SmartPLS. Marketing Bulletin, 24(1), 1-32.

Zachawerus, J., \& Soekiman, A. (2018). Faktor-Faktor Yang Mempengaruhi Kesuksesan. Jurnal Infrastruktur, 4(01), 26-33.

Zait, A., \& Bertea, P. E. (2011). Methods for Testing Discriminant Validity. Management \& Marketing, IX(2), 217-224. 